\title{
G sonatem \\ Risk Factors Related to Weight Gain for Chines During Home Confinement in COVID-19 Pandemic: An Observational Retrospective Study
}

\section{Qing-Song Xia}

Tongji Hospital of Tongji Medical College of Huazhong University of Science and Technology https://orcid.org/0000-0002-8948-2573

\section{Fan Wu}

Tongji Hospital of Tongji Medical College of Huazhong University of Science and Technology

\section{Ming-Ming Gong}

Tongji Hospital of Tongji Medical College of Huazhong University of Science and Technology

\section{Yan Zhao}

Tongji Hospital of Tongji Medical College of Huazhong University of Science and Technology

\section{Ding-Kun Wang}

Tongji Hospital of Tongji Medical College of Huazhong University of Science and Technology

\section{Zhao-Yi Huang}

Tongji Hospital of Tongji Medical College of Huazhong University of Science and Technology Hui Dong

Tongji Hospital of Tongji Medical College of Huazhong University of Science and Technology

\section{Li-Jun Xu}

Tongji Hospital of Tongji Medical College of Huazhong University of Science and Technology Jing Gong ( $\nabla$ jgongtcm@126.com )

Tongji Hospital of Tongji Medical College of Huazhong University of Science and Technology https://orcid.org/0000-0003-0757-2127

\section{Fu-Er Lu}

Tongji Hospital of Tongji Medical College of Huazhong University of Science and Technology

\section{Research}

Keywords: weight gain, risk factor, lose weight, Chinese, self-quarantine

Posted Date: August 10th, 2020

DOI: https://doi.org/10.21203/rs.3.rs-55697/v1 
License: (c) (i) This work is licensed under a Creative Commons Attribution 4.0 International License. Read Full License 


\section{Abstract}

Objective: The observational study was intended to explore the weight changes and risk factors of weight gain during the self-quarantine and find available methods to lose weight.

Method: This was an online retrospective observational study investigating the weight changes before and after home confinement. A total of 530 participants completed the online questionnaire. diet, sleep, self-reported depression, disease history and exercise information possibly relating to weight changes were incorporated into the questionnaire. The differences among four groups (underweight, normal weight, overweight and obesity) in BMI change and weight change were compared, and the risk factors of weight gain was also analyzed by multiple linear regression analysis.

Result. Participants were mostly between 21-50 years old, getting an average weight change of $0.82 \pm 3.31 \mathrm{~kg}$, and an average BMl change of $0.35[-0.37,1.00] .43 .77 \%$ of them gained weight by $2.99 \pm 2.29 \mathrm{~kg}$ averagely. People with normal weight were easier to gain weight than obese group $(p=0.001)$. There were differences in food intake $(p<0.001)$, eating habits $(p<0.001)$, taste preference $(p=0.047)$, daily exercise step change $(p=0.007)$, exercise $(p=0.02)$ between non-weight gain group and weight gain group. The multiple linear regression revealed that weight gains were associated with sex $(p=0.002)$, food intake $(p=0.004)$, current daily exercise step $(p=0.009)$ and self-reported depression $(p=0.002)$ and weight loss was related to food intake $(p=0.004)$ and pre-BMI $(p=0.001)$.

Conclusion: Eating irregularly, increasing food intake, self-reported depression and decreased daily steps were risk factors of weight gain, yet weight loss was related to decreased food intake and pre-BMI.

\section{Introduction}

In response to public health incident of COVID-19, a lot of provinces in China announced the launch of a first-level response. A series of policies including traffic lockdown and home quarantine were formulated to lower the spread of the virus by keeping social distance and restricting needless egress. Home quarantine has indeed significantly reduced the spread of the virus, allowing the epidemic to be effectively controlled. Not only in China, many people all around the world were proposed to self-isolate at home to reduce social interaction during the COVID-19 pandemic (1).

However, emotional and lifestyle changes during self-quarantine might increase the risks of obesity during quarantine (2-4). Home confinement for several months could lead to weight gain, further increasing incidence of obesity (5).To many patients in Italy, weight gain was found related to increased self-reported anxiety or depression and not consuming healthy food in obese adults according to multiple regression analysis (6). In Poland, almost $30 \%$ of people gain weight of $3.0 \pm 1.6 \mathrm{~kg}$, and it seemed that overweight, obese and older individuals were more likely to gain weight (7). Because of school closures resulting from COVID-19, the risk of weight gain increased for children in USA $(8,9)$. 
In China, the breakout of the epidemic coincided with the Spring Festival. Some studies show that, the mean weight increased approximately by $0.5 \mathrm{~kg}$ during the holiday period, compared with the weight before the holidays $(10,11)$, and that could be related to the increase in food intake $(12,13)$. It was not clear whether the isolation during the holiday led to weight gain and increased $\mathrm{BMI}$ in China. The online observational retrospective survey sought to probe the weight changes and factors resulting in weight gain during the home confinement.

\section{Method}

\section{Participants and procedures}

This was an observational study. We promulgated this questionnaire on the WeChat platform on May 23, 2020. Participants who completed the online questionnaire from May 23 to May 31 were gonging to be included in the retrospective observational survey. A total of 530 participants accomplished the questionnaire in the survey. All participants came from China, and approximately half of them were from Hubei Province.

\section{Questionnaire}

This was an anonymous questionnaire which was designed on the web (https://www.wjx.cn/login.aspx). Before filling out the questionnaire, protected individual privacy and the purpose of this survey were notified. The weight change, BMI change, exercise, diet, sleep time, self-reported depression, ideal weight and satisfaction of current weight during the pandemic period were assessed in this questionnaire.

The main content of the questionnaire is as follows:

1. Demographics. The descriptive information included gender, age, height, pre-weight before home confinement, weight after home confinement and existing physical illness. BMI was calculated based on weight and height $\left(\mathrm{BMI}=\right.$ weight $(\mathrm{kg}) /$ height $\left.(\mathrm{m})^{2}\right)$, which categorized into categories of underweight (BMI < 18.5), normal weight $(18.5 \leq \mathrm{BMI}<25)$, overweight $(25 \leq \mathrm{BMI}<30)$, obesity (BMI $\geq 30$ ).

2. Diet information. People were asked to choose the change of food intake than that before the home confinement (including increase, fixedness and decrease), the diet habit (including eating multiple small meals, eating less, engorgement, eating three meals regularly and eating irregular meals), the preference of taste (including spicy, sweet, salty, tart and light). Only one option could be selected for these 3 aforementioned questions. The last question was about the type of diet. Participants could choose more than one type of diet which they preferred.

3. Exercise information. An inquiry into the exercise details during the lockdown was made as a part of the questionnaire. This part composed of the average exercise steps before the pandemic (including below 1000 steps, $1000-5000$ steps, $5000-10000$ steps, $10000-15000$ steps and at least 15000 steps), the average exercise steps during lockdown (same as the previous question options), the frequency of exercise (including 1-3 times/week, 4-6 times/week and everyday), the average 
exercise time every exercise (including below $0.5 \mathrm{~h}, 0.5-1 \mathrm{~h}, 1-2 \mathrm{~h}$ and at least $2 \mathrm{~h}$ ). Single choice was set for the above four questions. Another question was about the methods of exercise that subjects selected or recommended. If participant didn't do exercise, they could skip this part. The daily exercise step was counted and supplied by We-chat app for everyone.

4. Others. Containing sleep time (including less 6 h, 6-8 h and over 8 h), self-reported depression (including no depression, mild depression, moderate depression and severe depression), satisfaction of current weight (yes/no), and ideal weight (losing $2.5 \mathrm{~kg}$ at most, losing 2.5-5 kg, losing $5 \mathrm{~kg}$ at least, maintaining the status quo, gaining $2.5 \mathrm{~kg}$ at most, gaining $2.5-5 \mathrm{~kg}$ and gain $5 \mathrm{~kg}$ at least). Only one answer could be chosen for the above four questions respectively.

\section{Analytic strategy}

All statistical analysis was performed using Rstudio software (Rstudio version 1.2.5042, 2009-2020 RStudio, Inc.). Normal distribution data were expressed as means \pm standard deviation, and skewed distribution data were expressed as median[q1,q3]. Descriptive statistics summarized the demographic features of participants, and the percentages of each option were accounted. About statistic differences between non-weight gain group and weight gain group during the home confinement, chi-sq.test was used for categorical variables, kruskal.test was used for continuous variable of skewed distribution, and ttest was employed for continuous variable of normal distribution. The same statistical methods were used for comparisons between participators with non-increased BMI and those with increased BMI during the home confinement. Comparing the difference between weights before and after home confinement was carried on by paired t-test, and the difference of BMI before and after home confinement was analyzed by Wilcox.test. The multiple linear regression models were applied to assess the contribution of other variables to weight gain and weight loss. Analyzing the difference of BMI change and weight change among four groups (underweight, normal weight, overweight and obesity) was performed by Kruskal-Wallis test and analysis of variance respectively.

\section{Result}

\section{Descriptive data}

A total of 530 participants (356 females and 174 males) accomplished the online questionnaire in the survey. Descriptive statistics are presented in Table 1. Participants ranged from 21 to 50 years old mostly, having an average weight change of $0.82 \pm 3.31 \mathrm{~kg}$, and an average BMI change of $0.35[-0.37,1.00]$. It was worth noting that $43.77 \%$ participants gained weight with an average change of $2.99 \pm 2.29 \mathrm{~kg}$. About $30 \%$ participants lost weight with an average decrease of $2.88 \pm 1.99 \mathrm{~kg}$. In item of diet, roughly $26 \%$ participants increased food intake during self-isolation, and approximately $27 \%$ individuals had irregular eating habits. About $40 \%$ people in the survey prefer to eat spicy food. In exercise, about $58 \%$ people didn't do exercise at home, and over half of participant had decreased daily exercise steps due to lockdown during the pandemic. More than half of individuals had sufficient sleep time, but roughly $40 \%$ people had varying degrees of self-reported depression. Over half participants were not pleased with their 
current weight and longed for losing weight regardless of weight gain people or weight loss people (Fig. 1A and B). 
Table 1

Basic characteristics of participants

\begin{tabular}{|c|c|c|c|c|c|}
\hline & level & Overall & & level & Overall \\
\hline $\mathrm{n}$ & & 530 & & & 530 \\
\hline \multirow[t]{2}{*}{$\operatorname{sex}(\%)$} & female & $\begin{array}{l}356 \\
(67.2)\end{array}$ & $\begin{array}{l}\text { taste preference } \\
\text { (\%) }\end{array}$ & spicy & $\begin{array}{l}214 \\
(40.4)\end{array}$ \\
\hline & male & $\begin{array}{l}174 \\
(32.8)\end{array}$ & & sweet & 38 ( 7.2) \\
\hline \multirow[t]{8}{*}{ age (\%) } & under $10 y$ & $2(0.4)$ & & salty & 78 (14.7) \\
\hline & $11 y-20 y$ & $40(7.5)$ & & tart & $12(2.3)$ \\
\hline & $21 y-30 y$ & $\begin{array}{l}204 \\
(38.5)\end{array}$ & & light & $\begin{array}{l}188 \\
(35.5)\end{array}$ \\
\hline & $31 y-40 y$ & $\begin{array}{l}123 \\
(23.2)\end{array}$ & $\begin{array}{l}\text { daily exercise } \\
\text { step change (\%) }\end{array}$ & $\begin{array}{l}\text { decrease by } \\
10000 \text { steps at } \\
\text { least }\end{array}$ & $29(5.5)$ \\
\hline & $41 y-50 y$ & $64(12.1)$ & & $\begin{array}{l}\text { decrease by } 5000 \\
\text { to } 10000 \text { steps }\end{array}$ & $\begin{array}{l}133 \\
(25.1)\end{array}$ \\
\hline & $51 y-60 y$ & $52(9.8)$ & & $\begin{array}{l}\text { decrease by } 1000 \\
\text { to } 5000 \text { steps }\end{array}$ & $\begin{array}{l}199 \\
(37.5)\end{array}$ \\
\hline & $61 y-70 y$ & 35 ( 6.6) & & $\begin{array}{l}\text { almost } \\
\text { unchanged }\end{array}$ & $\begin{array}{l}149 \\
(28.1)\end{array}$ \\
\hline & over 70y & $10(1.9)$ & & $\begin{array}{l}\text { increase by } 1000 \\
\text { to } 5000 \text { steps }\end{array}$ & 19 ( 3.6$)$ \\
\hline $\begin{array}{l}\text { height (m) } \\
\text { (mean (SD)) }\end{array}$ & & $\begin{array}{l}1.64 \\
(0.09)\end{array}$ & & $\begin{array}{l}\text { increase by } 5000 \\
\text { to } 10000 \text { steps }\end{array}$ & $1(0.2)$ \\
\hline $\begin{array}{l}\text { pre-weight(kg) } \\
\text { (mean (SD)) }\end{array}$ & & $\begin{array}{l}61.17 \\
(12.48)\end{array}$ & exercise (\%) & yes & $\begin{array}{l}218 \\
(41.1)\end{array}$ \\
\hline $\begin{array}{l}\text { current } \\
\text { weight(kg) } \\
\text { (mean (SD)) }\end{array}$ & & $\begin{array}{l}61.99 \\
(12.70)\end{array}$ & & no & $\begin{array}{l}312 \\
(58.9)\end{array}$ \\
\hline $\begin{array}{l}\text { weight } \\
\text { change(kg) } \\
\text { (mean (SD)) }\end{array}$ & & $\begin{array}{l}0.82 \\
(3.31)\end{array}$ & sleep time (\%) & less $6 \mathrm{~h}$ & $64(12.1)$ \\
\hline $\begin{array}{l}\text { pre-BMI (median } \\
\text { [IQR]) }\end{array}$ & & $\begin{array}{l}21.97 \\
{[20.07} \\
24.38]\end{array}$ & & $\begin{array}{l}\text { between } 6 \mathrm{~h} \text { and } \\
8 \mathrm{~h}\end{array}$ & $\begin{array}{l}315 \\
(59.4)\end{array}$ \\
\hline $\begin{array}{l}\text { current BMI } \\
\text { (mean (SD)) }\end{array}$ & & $\begin{array}{l}22.29 \\
{[20.20} \\
24.89]\end{array}$ & & over $8 \mathrm{~h}$ & $\begin{array}{l}151 \\
(28.5)\end{array}$ \\
\hline
\end{tabular}




\begin{tabular}{|c|c|c|c|c|c|}
\hline & level & Overall & & level & Overall \\
\hline $\begin{array}{l}\text { BMI change } \\
\text { (median [IQR]) }\end{array}$ & & $\begin{array}{l}0.35 \\
{[-0.37} \\
1.00]\end{array}$ & $\begin{array}{l}\text { self-reported } \\
\text { depression (\%) }\end{array}$ & no & $\begin{array}{l}313 \\
(59.1)\end{array}$ \\
\hline \multirow{2}{*}{$\begin{array}{l}\text { existing } \\
\text { physical illness } \\
\text { (\%) }\end{array}$} & yes & $\begin{array}{l}117 \\
(22.1)\end{array}$ & & mild & $\begin{array}{l}131 \\
(24.7)\end{array}$ \\
\hline & no & $\begin{array}{l}413 \\
(77.9)\end{array}$ & & moderate & 79 (14.9) \\
\hline \multirow[t]{3}{*}{ food intake (\%) } & increase & $\begin{array}{l}139 \\
(26.2)\end{array}$ & & severe & $7(1.3)$ \\
\hline & decrease & 99 (18.7) & Pre-BMI & underweight & $55(10.4)$ \\
\hline & fixedness & $\begin{array}{l}292 \\
(55.1)\end{array}$ & & Normal weight & $366(69.1)$ \\
\hline \multirow[t]{5}{*}{$\begin{array}{l}\text { eating habits } \\
\text { (\%) }\end{array}$} & $\begin{array}{l}\text { eat multiple } \\
\text { small meals }\end{array}$ & $43(8.1)$ & & overweight & $90(17)$ \\
\hline & eat less & $29(5.5)$ & & obesity & 19(3.5) \\
\hline & engorgement & $16(3.0)$ & & & \\
\hline & $\begin{array}{l}\text { eat three } \\
\text { meals } \\
\text { regularly }\end{array}$ & $\begin{array}{l}297 \\
(56.0)\end{array}$ & & & \\
\hline & $\begin{array}{l}\text { eat irregular } \\
\text { meals }\end{array}$ & $\begin{array}{l}145 \\
(27.4)\end{array}$ & & & \\
\hline
\end{tabular}

\section{Characteristic differences between non-increased weight group and increased weight group}

There were considerable differences in different items of food intake, eating habits $(p<0.001)$, taste preference $(p<0.05)$, daily exercise step change $(p=0.007)$ and exercise or not $(p=0.02)$ (Table 2$)$ between non-increased weight group and increased weight group. Table S1 showed characteristic differences between non-increased BMI and increased BMI. Through assessing the weight and BMI changes before and after the home confinement, significant difference in weight change but not in BMI change was found (Table S2). So we further analyzed what caused weight gain and weight loss by multiple linear regression. 
Table 2

Characteristic differences between non-weight gain group and weight gain group during the home confinement.

\begin{tabular}{|c|c|c|c|c|}
\hline & level & $\begin{array}{l}\text { Non-weight } \\
\text { gain }\end{array}$ & $\begin{array}{l}\text { weight } \\
\text { gain }\end{array}$ & p \\
\hline $\mathrm{n}$ & & 232 & 298 & \\
\hline \multirow[t]{2}{*}{$\operatorname{sex}(\%)$} & female & $160(69.0)$ & $\begin{array}{l}196 \\
(65.8)\end{array}$ & 0.494 \\
\hline & male & $72(31.0)$ & $\begin{array}{l}102 \\
(34.2)\end{array}$ & \\
\hline \multirow[t]{8}{*}{ age (\%) } & under 10y & $1(0.4)$ & $1(0.3)$ & 0.889 \\
\hline & $11 y-20 y$ & $17(7.3)$ & $23(7.7)$ & \\
\hline & $21 y-30 y$ & $90(38.8)$ & $\begin{array}{l}114 \\
(38.3)\end{array}$ & \\
\hline & $31 y-40 y$ & $59(25.4)$ & $64(21.5)$ & \\
\hline & $41 y-50 y$ & $24(10.3)$ & $40(13.4)$ & \\
\hline & $51 y-60 y$ & $20(8.6)$ & $32(10.7)$ & \\
\hline & $61 y-70 y$ & $17(7.3)$ & $18(6.0)$ & \\
\hline & over 70y & $4(1.7)$ & $6(2.0)$ & \\
\hline height (m) (mean (SD)) & & $1.64(0.08)$ & $\begin{array}{l}1.65 \\
(0.09)\end{array}$ & 0.732 \\
\hline \multirow{2}{*}{$\begin{array}{l}\text { existing physical illness } \\
\text { (\%) }\end{array}$} & yes & $49(21.1)$ & $68(22.8)$ & 0.717 \\
\hline & no & $183(78.9)$ & $\begin{array}{l}230 \\
(77.2)\end{array}$ & \\
\hline \multirow[t]{3}{*}{ food intake (\%) } & increase & $26(11.2)$ & $\begin{array}{l}113 \\
(37.9)\end{array}$ & $<.001^{\star * *}$ \\
\hline & decrease & $75(32.3)$ & $24(8.1)$ & \\
\hline & fixedness & $131(56.5)$ & $\begin{array}{l}161 \\
(54.0)\end{array}$ & \\
\hline \multirow[t]{4}{*}{ eating habits (\%) } & eat multiple small meals & $24(10.3)$ & 19 ( 6.4) & $<.001$ ¿ \\
\hline & eat less & $22(9.5)$ & $7(2.3)$ & \\
\hline & engorgement & $3(1.3)$ & $13(4.4)$ & \\
\hline & eat three meals regularly & $136(58.6)$ & $\begin{array}{l}161 \\
(54.0)\end{array}$ & \\
\hline
\end{tabular}




\begin{tabular}{|c|c|c|c|c|}
\hline & level & $\begin{array}{l}\text { Non-weight } \\
\text { gain }\end{array}$ & $\begin{array}{l}\text { weight } \\
\text { gain }\end{array}$ & p \\
\hline & eat irregular meals & $47(20.3)$ & $98(32.9)$ & \\
\hline \multirow[t]{5}{*}{ taste preference (\%) } & spicy & $93(40.1)$ & $\begin{array}{l}121 \\
(40.6)\end{array}$ & $0.047^{\star}$ \\
\hline & sweet & $10(4.3)$ & $28(9.4)$ & \\
\hline & salty & $30(12.9)$ & $48(16.1)$ & \\
\hline & tart & $4(1.7)$ & $8(2.7)$ & \\
\hline & light & $95(40.9)$ & 93 (31.2) & \\
\hline \multirow[t]{6}{*}{$\begin{array}{l}\text { daily exercise step change } \\
\text { (\%) }\end{array}$} & $\begin{array}{l}\text { decrease by } 10000 \text { steps at } \\
\text { least }\end{array}$ & $14(6.0)$ & $15(5.0)$ & $0.007 * *$ \\
\hline & $\begin{array}{l}\text { decrease by } 5000 \text { to } 10000 \\
\text { steps }\end{array}$ & $41(17.7)$ & $92(30.9)$ & \\
\hline & $\begin{array}{l}\text { decrease by } 1000 \text { to } 5000 \\
\text { steps }\end{array}$ & 88 (37.9) & $\begin{array}{l}111 \\
(37.2)\end{array}$ & \\
\hline & almost unchanged & 77 (33.2) & $72(24.2)$ & \\
\hline & $\begin{array}{l}\text { increase by } 1000 \text { to } 5000 \\
\text { steps }\end{array}$ & $11(4.7)$ & $8(2.7)$ & \\
\hline & $\begin{array}{l}\text { increase by } 5000 \text { to } 10000 \\
\text { steps }\end{array}$ & $1(0.4)$ & $0(0.0)$ & \\
\hline \multirow[t]{2}{*}{ exercise (\%) } & yes & $109(47.0)$ & $\begin{array}{l}109 \\
(36.6)\end{array}$ & $0.020 *$ \\
\hline & no & $123(53.0)$ & $\begin{array}{l}189 \\
(63.4)\end{array}$ & \\
\hline \multirow[t]{3}{*}{ sleep time (\%) } & less $6 \mathrm{~h}$ & $26(11.2)$ & $38(12.8)$ & 0.261 \\
\hline & between $6 \mathrm{~h}$ and $8 \mathrm{~h}$ & $147(63.4)$ & $\begin{array}{l}168 \\
(56.4)\end{array}$ & \\
\hline & over $8 \mathrm{~h}$ & $59(25.4)$ & $92(30.9)$ & \\
\hline \multirow[t]{4}{*}{$\begin{array}{l}\text { self-reported depression } \\
\text { (\%) }\end{array}$} & no & $143(61.6)$ & $\begin{array}{l}170 \\
(57.0)\end{array}$ & 0.276 \\
\hline & mild & $52(22.4)$ & $79(26.5)$ & \\
\hline & moderate & $32(13.8)$ & $47(15.8)$ & \\
\hline & severe & $5(2.2)$ & $2(0.7)$ & \\
\hline
\end{tabular}




\section{Factors affecting weight change}

Multiple linear regression was adopted to investigate the factors for weight change, including weight gain and weight loss. Table S3 showed the result of multiple linear regression of weight change. We filtered out the following variables: gender, food intake, eating habits, daily exercise step after home confinement, pre-BMI and self-reported depression. Gender $(p<0.001)$, food intake $(p<0.001)$, eating habits $(p<0.001)$, daily exercise step after home confinement $(p<0.001)$, and pre-BMI $(p<0.01)$ were found related to weight. In the multiple linear regression of weight gain, the variables: sex, food intake, daily exercise step after home confinement and self-reported depression were chosen to make a statistical model (Table 3). There was statistical significance in sex (male) $(p<0.01)$, food intake $(p<0.01)$, daily exercise step after home confinement $(p<0.01)$ and self-reported depression $(p<0.01)$ for weight gain. It seemed that male objects were easier to gain weight compared with female (Table 4). In the multiple line regression of weight-loss, gender, age, height, food intake, eating habits and pre-BMI were selected to make multiple regression model, but there were statistic differences in food intake and pre-BMI.

Table 3

Multiple Linear regression of weight-gain

\begin{tabular}{|c|c|c|c|c|}
\hline term & estimate & std.error & statistic & p.value \\
\hline (Intercept) & 5.17 & 0.72 & 7.18 & $<0.001^{\star \star *}$ \\
\hline sex(male) & -0.87 & 0.27 & -3.19 & $0.002^{\star \star}$ \\
\hline food intake & -0.39 & 0.14 & -2.88 & $0.004 * \star$ \\
\hline current daily exercise step & -0.42 & 0.16 & -2.61 & $0.009 * \star$ \\
\hline self-reported depression & 0.52 & 0.17 & 3.15 & $0.002^{\star \star}$ \\
\hline \multicolumn{5}{|c|}{ F-statistic: 9.042 on 4 and 290 DF, p-value: $<0.001$} \\
\hline \multicolumn{5}{|c|}{ 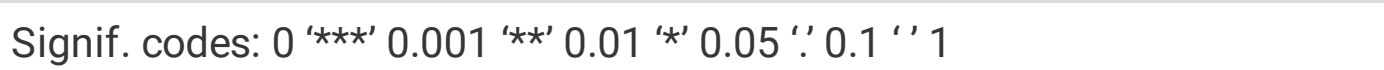 } \\
\hline
\end{tabular}


Table 4

Multiple Line regression of weight-loss

\begin{tabular}{|c|c|c|c|c|}
\hline term & estimate & std.error & statistic & p.value \\
\hline (Intercept) & 6.58 & 5.51 & 1.19 & 0.235 \\
\hline sex(male) & -0.68 & 0.49 & -1.40 & 0.163 \\
\hline age & -0.15 & 0.10 & -1.50 & 0.137 \\
\hline height (m) & -4.21 & 2.87 & -1.47 & 0.144 \\
\hline food intake & 0.62 & 0.21 & 2.95 & $0.004 * \star$ \\
\hline eating habits & 0.20 & 0.11 & 1.82 & 0.071 \\
\hline pre-BMI & -0.13 & 0.04 & -3.30 & $0.001^{* *}$ \\
\hline \multicolumn{5}{|c|}{ F-statistic: 12.62 on 3 and 153 DF, p-value: $<0.001$} \\
\hline \multicolumn{5}{|c|}{ 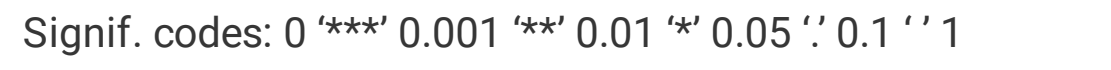 } \\
\hline
\end{tabular}

It was interesting that pre-BMI associating with weight change, so we analyzed the difference among four groups, namely underweight, normal weight, overweight and obesity, in BMI change and weight change by Kruskal-Wallis test and analysis of variance respectively. The result showed that there was difference in BMl change $(p<0.05)$ and weight change $(p<0.05)$ among four groups during home confinement (Table S4). Significant difference was found between normal weight group and obesity group in BMI change and weight change (Table S5). Since the previous study had shown that obese individuals were more likely to gain weight during the epidemic(7), we further compared medium number and mean of normal weight and obesity group in BMI change and weight change respectively, and found that the medium number of normal weight group was greater than obesity group $(p=0.0018)$ (Fig. 1D), and the mean of normal weight group was larger than obesity group by using turkey multiple comparisons (Figure S1); in other words, participants with normal weight were easier to gain weight than obese participants. Small samples (19 obese objects) might be the main course.

In a word, the social behaviors such as eating habits, food intake and daily exercise step and self-reported depression were reverent to weight change, in addition to uncontrollable factors such as height, age, and gender. The results revealed that weight gain was associated with food intake, daily exercise step and self-reported depression, and weight loss was related to food intake and pre-BMI. Next, we discussed in detail the differences in diet and exercise between weight gain and weight loss participants.

\section{The differences in diet and exercise between weight gain and weight loss participants}

According to the result of multiple linear regression, the social behaviors: exercise and diet were closely associated with weight change. So we analyzed the differences in diet and exercise between weight gain 
and weight loss participants, aiming to provide suggestions to people who wished to lose weight (Fig. 1A, 1B).

In exercise, most participants walked below 10000 steps every day before home confinement, and the daily exercise step was below 5000 steps for most people during the quarantine (Fig. 1C, Fig. 2A) regardless of weight change. Roughly half of the people didn't do exercise, especially in weight-gain group. Over 30\% of weight-loss people had an average exercise time of 0.5-1 h (Fig. 2B). Exercise frequency of weight-loss group focused on 1-3 times/week and 4-6 times/week (Fig. 2C). By coincidence, aerobics and speed walking were become the most commonly adopted exercises for both weight-gain and non-weight gain group (Fig. 2D). The multiple linear regression referred that eating habits affected the weight change (Table S3), however, more people ate irregularly and ate three meals regularly in weight-gain group than the other group (Fig. 3A), and eating irregular meals became one possible reason of weight gain. The percentage of people who prefer to eat light and salty food in weight gain group was higher than weight loss group (Fig. 3B). Approximately 40\% people in non-weight gain group decreased their food intake (Fig. 3C), and the multiple linear regression also showed that food intake was relevant to weight loss and weight gain (Tables 4 and 5), which was the main cause of weight loss and weight gain. There was no difference in type of diet between weight-gain group and weight-loss group (Fig. 3D). In short, decreased food intake could be the main reason of weight loss, nevertheless eating irregularly and increased food intake was associated with weight-gain. The decrease in daily exercise steps led to weight change overall.

\section{Discussion}

The survey including 530 participants was dedicated to investigating the relation between weight changes and lifestyles of Chinese people during the epidemic. The present survey indicates that $43.77 \%$ participants gained weight by $2.99 \pm 2.29 \mathrm{~kg}$ averagely during a self-quarantine for several months. The imbalance between energy intake and energy expenditure is the essential cause of weight change. Excessive energy intake may result in increased fat storage capacity and weight gain, even obesity, insulin resistance and lipotoxicity in severe cases (14). The problematic eating behaviors such as frequent overeating, snacking after dinner, eating in response to stress are the risk factors for weight gain during the self-isolation in USA and Poland $(15,16)$. Even though the weight gain was slight relatively, this small change in weight for adults may contribute to substantial increases over decades (5).

Because of the impact of self-isolation and holidays, people have reduced physical activity especially in daily exercise step change. People were easier to gain weight in average of $0.5 \mathrm{~kg}$ during holiday than usual $(12,17)$. Unhealthy dietary habits, such as irregular eating and excessive food intake, are the essential factors resulting in weight gain. Nevertheless, sleep time was not related to weight change in our survey. However, it is worth paying attention to the generalized depressive symptoms and lower sleep quality during COVID-19 outbreak in China(2). 
As we all know, excessive food intake and lack of exercise could lead to gain weight. Nevertheless, gender and depression were associated to weight gain in our statistical analysis. The multiple linear regression of weight gain confirmed that males were easier to gain weight than females. Through analyzing the difference of four groups (underweight, normal weight, overweight and obesity) in BMI change and weight change before and during the home confinement, we found unexpectedly that participants of normal weight gained more weight than obese objects, resulting from small samples in obese group $(n=$ 19). Likewise, our survey indicated that self-reported depression was related to gain weight, which coincided with the previous study (6).

Most participants tended to lose weight and were not satisfied with current weight, and our study reveals that weight-loss people had a decreased food intake comparing weight-gain people. So if one want to lose weight during quarantine, these suggestions you can take: 1) don't take excessive food and minimize food intake based on maintaining daily energy requirements, 2) use the health management apps which is used to make a home exercise plan, boohee health app which can provide dietary guidance and record daily calorie intake, 3 ) take note of your weight every day by using weight scale to prevent from gaining weight, which is the effective way to manage weight $(17,18)$.

Although our survey provided an insight into variables affecting weight change during home confinement, there were some limitations: 1 ) due to the various educational backgrounds of the participants, the understanding of some items in the questionnaire was not clear, 2) since this questionnaire was published on the online platform, there was a lack of relevant professionals to guide participants to fill out the questionnaire, 3 ) in the option settings of some questions, objective standardization was not achieved, such as eating habits, and participants were more subjective.

The survey exposed that food intake was the key course of weight change, increasing food intake may resulting weight gain, and decreasing food intake may leading to weight loss, which coincided with the current clinical research on reducing food intake through alternate fasting to achieve weight loss $(19,20)$.

\section{Abbreviations}

BMl: Body mass index

COVID-19: Coronavirus disease 2019

SD: Standard deviation

IQR: Interquartile-range

Cl: Confidence interval

TCM: Technology of Chinese medicine

\section{Declarations}


Acknowledgments

We are very grateful for the assistance of the members of the Department of Integrated Traditional Chinese and Western Medicine, Tongji Hospital, Tongji Medical College, Huazhong University of Science and Technology and every participants who participated in this survey.

\section{Funding}

Supported by the National Natural Science Foundation of China, NO. 81904158 and TCM Modernization Research of National Key Research and Development Program, NO. 2018 YFC1704202

\section{Contribution}

Dong $\mathrm{H}$, Jing Gong and Lu FE designed the research. Gong MM, Zhao Y, Wang DK and Xu LJ collected the questionnaire. Xia QS and Wu F analyzed data. Xia QS and Gong J wrote the manuscript. Gong J and Lu FE supervised and approved the final version of the study.

\section{Ethics declaration}

\section{Ethics approval and consent to participate}

All participants voluntarily participated in this study and consented to use their information for scientific research.

\section{Consent for publication}

Not applicable.

\section{Competing interests}

There are no conflict of interest to declare.

\section{References}

1. Balanzá-Martínez V, Atienza-Carbonell B, Kapczinski F, De Boni RB. Lifestyle behaviours during the COVID-19 - time to connect. Acta psychiatrica Scandinavica. 2020;141(5):399-400.

2. Huang Y, Zhao N. Generalized anxiety disorder, depressive symptoms and sleep quality during COVID-19 outbreak in China: a web-based cross-sectional survey. Psychiatry research. 2020;288:112954.

3. Wang C, Pan R, Wan X, Tan Y, Xu L, Ho CS, et al. Immediate Psychological Responses and Associated Factors during the Initial Stage of the 2019 Coronavirus Disease (COVID-19) Epidemic among the General Population in China. International journal of environmental research and public health. 2020;17(5). 
4. Shi L, Lu ZA, Que JY, Huang XL, Liu L, Ran MS, et al. Prevalence of and Risk Factors Associated With Mental Health Symptoms Among the General Population in China During the Coronavirus Disease 2019 Pandemic. JAMA network open. 2020;3(7):e2014053.

5. Bhutani S, Cooper JA. COVID-19 related home confinement in adults: weight gain risks and opportunities. Obesity (Silver Spring, Md). 2020.

6. Pellegrini M, Ponzo V, Rosato R, Scumaci E, Goitre I, Benso A, et al. Changes in Weight and Nutritional Habits in Adults with Obesity during the "Lockdown" Period Caused by the COVID-19 Virus Emergency. Nutrients. 2020;12(7).

7. Di Renzo L, Gualtieri P, Pivari F, Soldati L, Attinà A, Cinelli G, et al. Eating habits and lifestyle changes during COVID-19 lockdown: an Italian survey. Journal of translational medicine. 2020;18(1):229.

8. Workman J. How Much May COVID-19 School Closures Increase Childhood Obesity? Obesity (Silver Spring, Md). 2020.

9. Rundle AG, Park Y, Herbstman JB, Kinsey EW, Wang YC. COVID-19-Related School Closings and Risk of Weight Gain Among Children. Obesity (Silver Spring, Md). 2020;28(6):1008-9.

10. Yanovski JA, Yanovski SZ, Sovik KN, Nguyen TT, O'Neil PM, Sebring NG. A prospective study of holiday weight gain. The New England journal of medicine. 2000;342(12):861-7.

11. Roberts SB, Mayer J. Holiday weight gain: fact or fiction? Nutrition reviews. 2000;58(12):378-9.

12. Bhutani S, Wells N, Finlayson G, Schoeller DA. Change in eating pattern as a contributor to energy intake and weight gain during the winter holiday period in obese adults. International journal of obesity (2005). 2020;44(7):1586-95.

13. Wilson MG, Padilla HM, Meng L, Daniel CN. Impact of a workplace holiday weight gain prevention program. Nutrition and health. 2019;25(3):173-7.

14. Clemmensen C, Petersen MB, Sørensen TIA. Will the COVID-19 pandemic worsen the obesity epidemic? Nature reviews Endocrinology. 2020:1-2.

15. Sidor A, Rzymski P. Dietary Choices and Habits during COVID-19 Lockdown: Experience from Poland. Nutrients. 2020;12(6).

16. Zachary Z, Brianna F, Brianna L, Garrett P, Jade W, Alyssa D, et al. Self-quarantine and weight gain related risk factors during the COVID-19 pandemic. Obesity research \& clinical practice. 2020;14(3):210-6.

17. Kaviani S, vanDellen M, Cooper JA. Daily Self-Weighing to Prevent Holiday-Associated Weight Gain in Adults. Obesity (Silver Spring, Md). 2019;27(6):908-16.

18. Houston M, vanDellen M, Cooper JA. Self-weighing Frequency and Its Relationship with Health Measures. American journal of health behavior. 2019;43(5):975-93.

19. Cienfuegos S, Gabel K, Kalam F, Ezpeleta M, Wiseman E, Pavlou V, et al. Effects of 4- and 6-h TimeRestricted Feeding on Weight and Cardiometabolic Health: A Randomized Controlled Trial in Adults with Obesity. Cell metabolism. 2020. 
20. Stekovic S, Hofer SJ, Tripolt N, Aon MA, Royer P, Pein L, et al. Alternate Day Fasting Improves Physiological and Molecular Markers of Aging in Healthy, Non-obese Humans. Cell metabolism. 2019;30(3):462-76.e6.

\section{Figures}

A

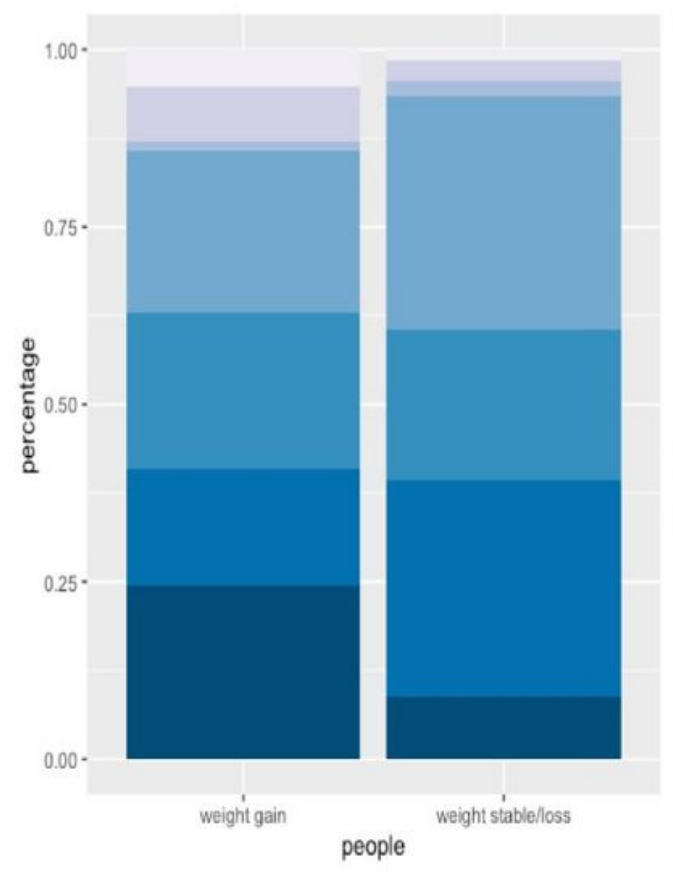

C
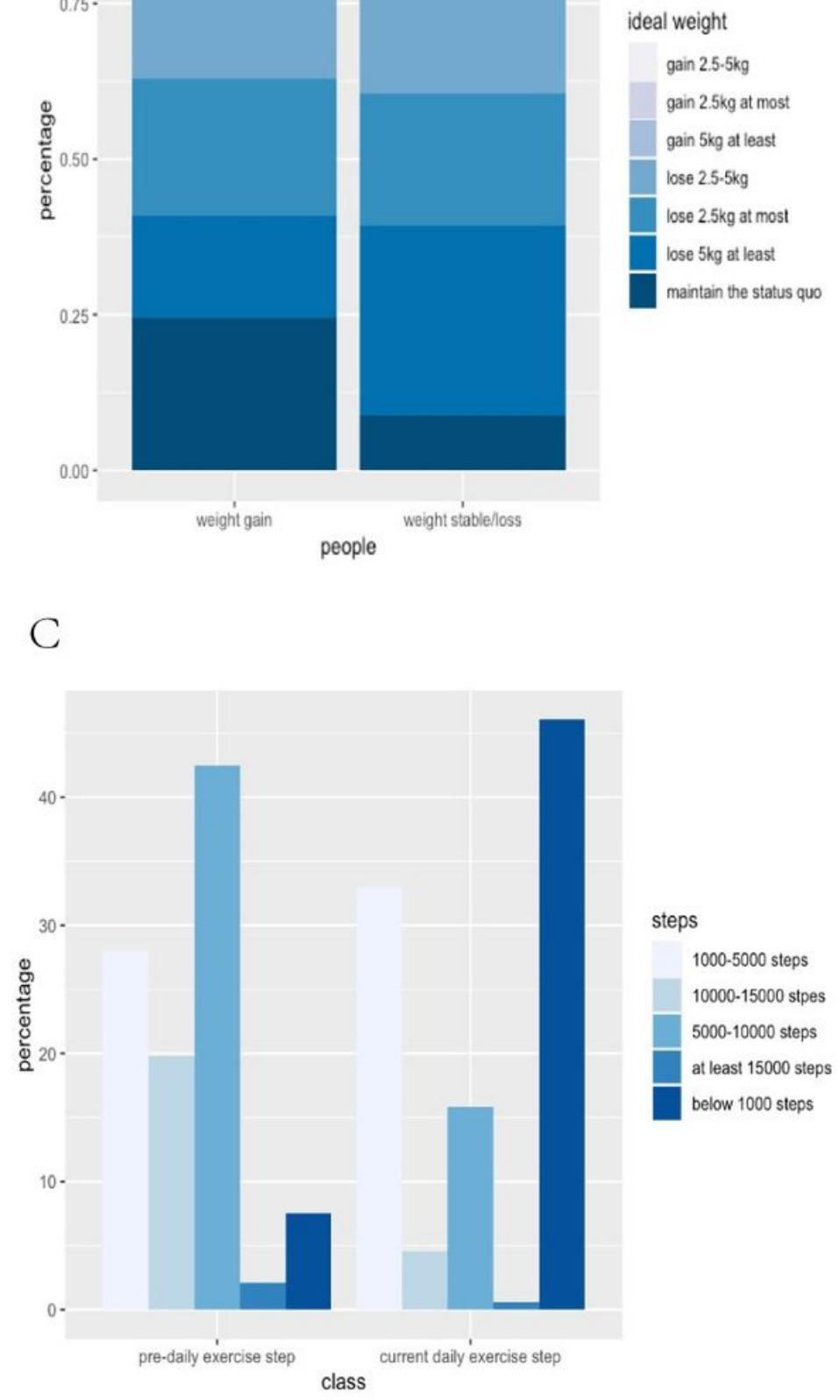

B

$\mathrm{D}$

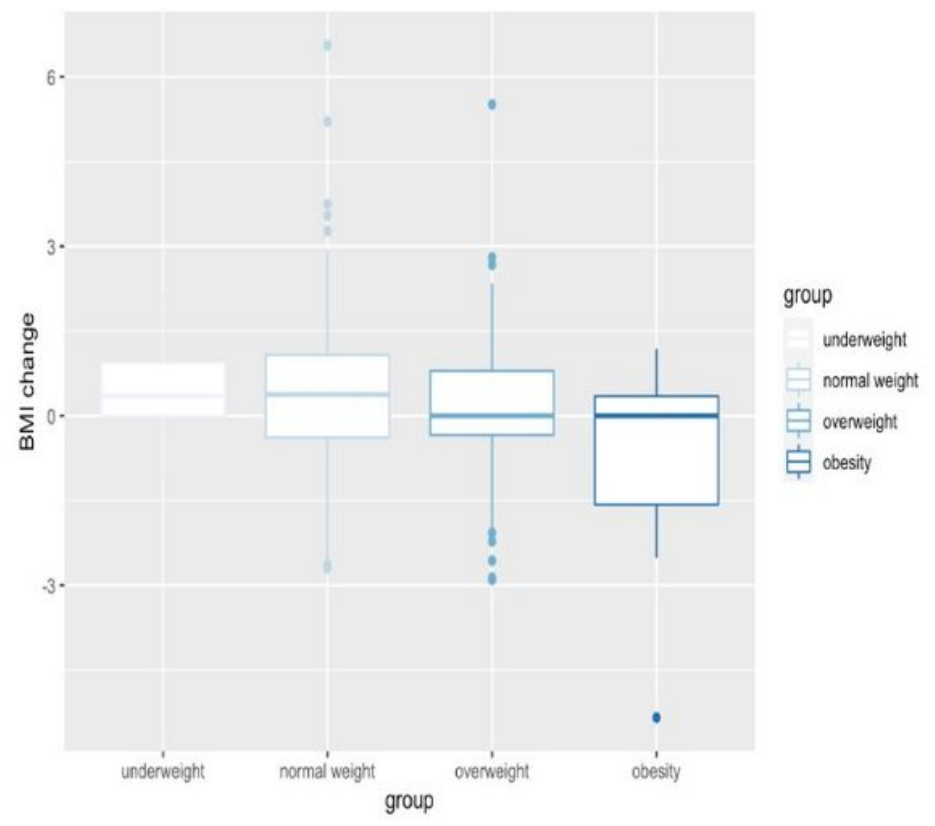

Figure 1 
Ideal and satisfaction of weight, daily steps and BMI changes of participants. Almost participants weren't satisfied with their current weight and wanted to lose weight. (A) ideal weight change, (B) satisfaction of current weight, (C) daily steps (D) BMI change of participants.

A

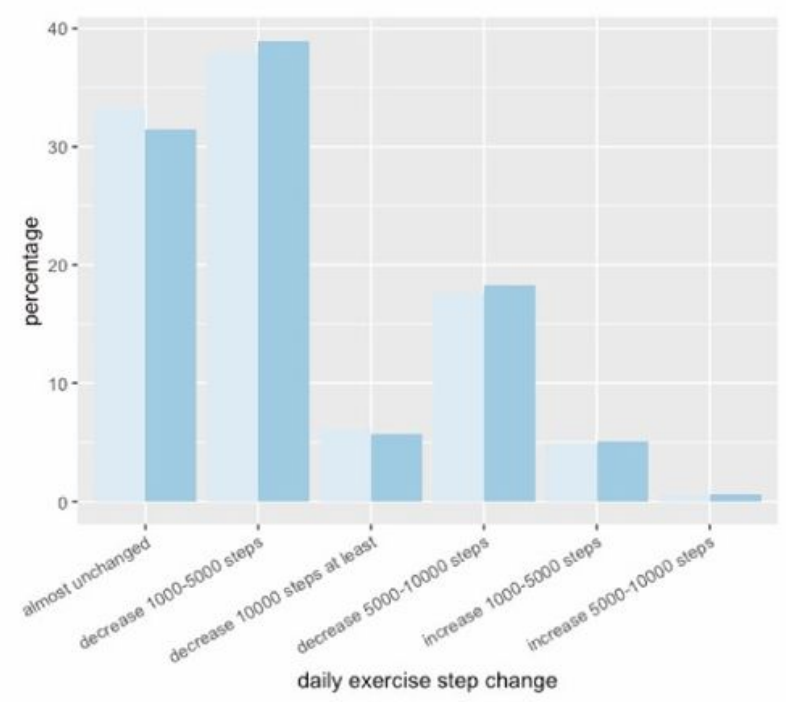

C

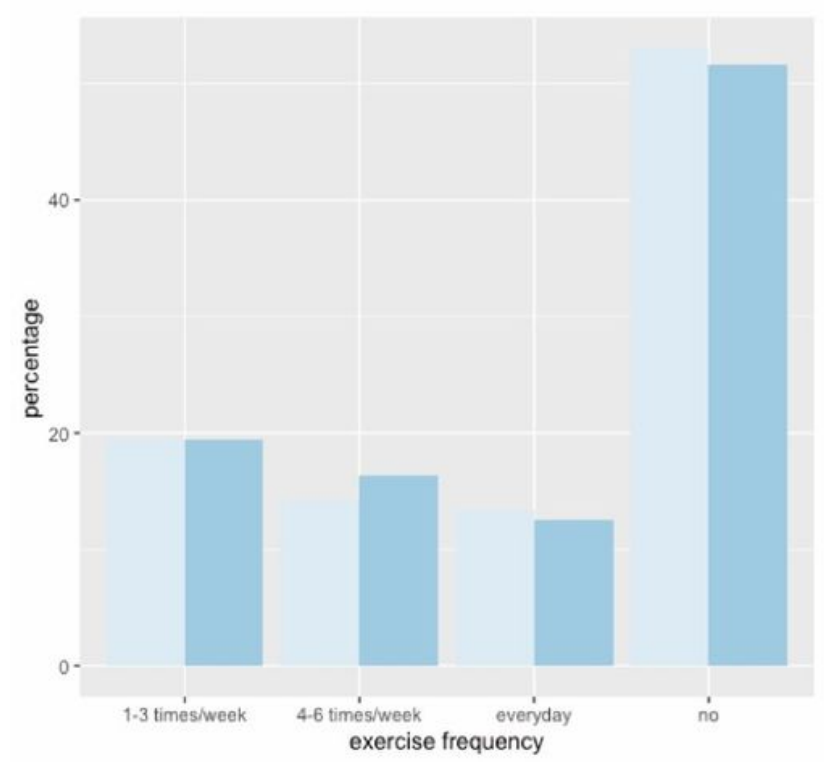

B
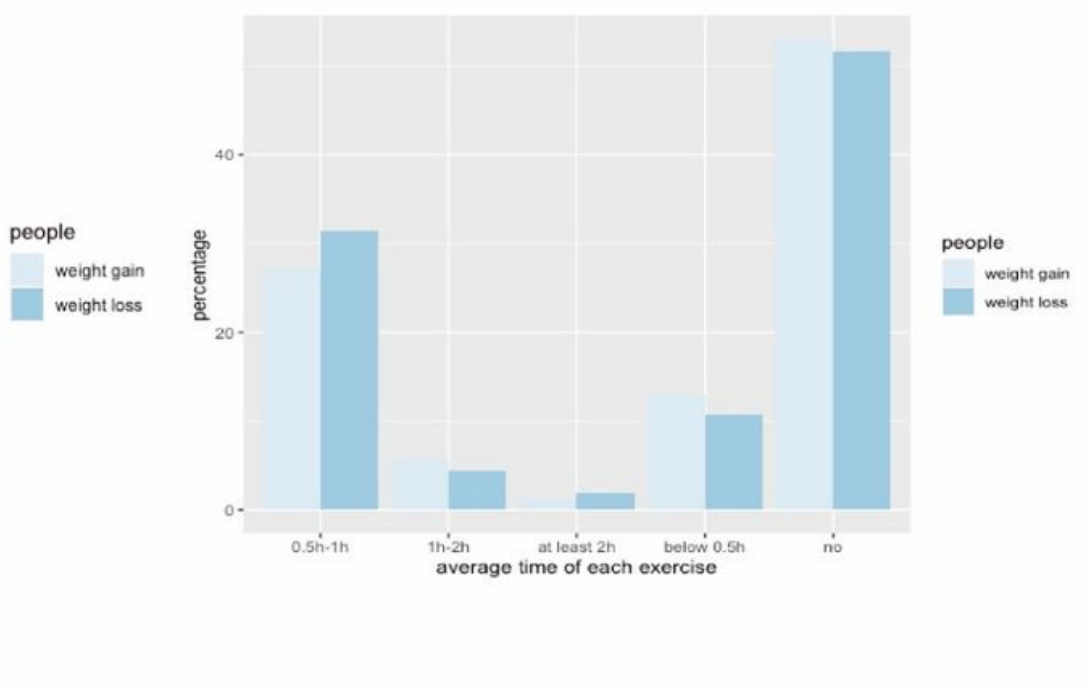

D

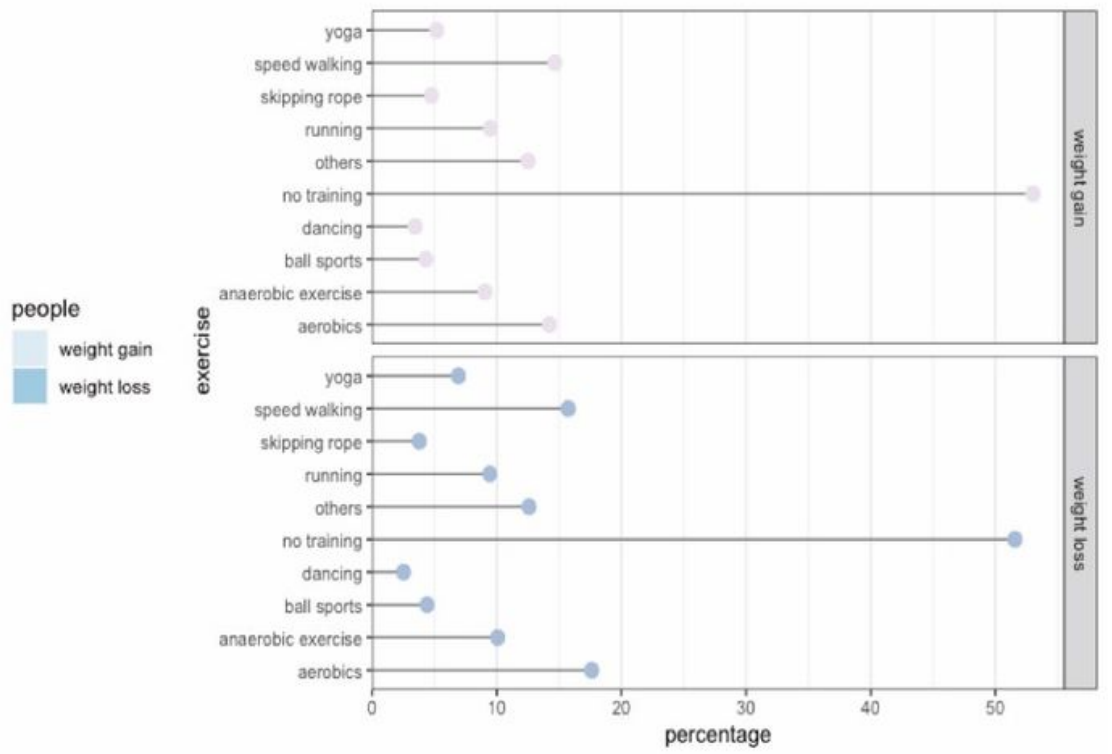

Figure 2

The differences of exercise between weight gain group and weight loss group during self-quarantine. (A) daily step change, (B) daily exercise time change, (C) exercise frequency, (D) exercise methods. 
A

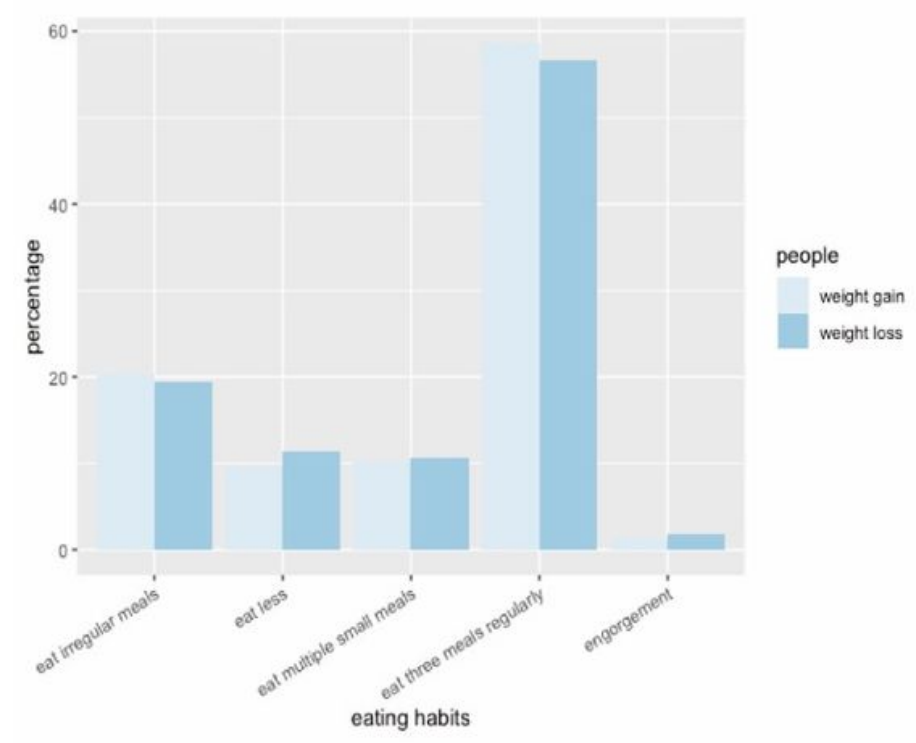

C

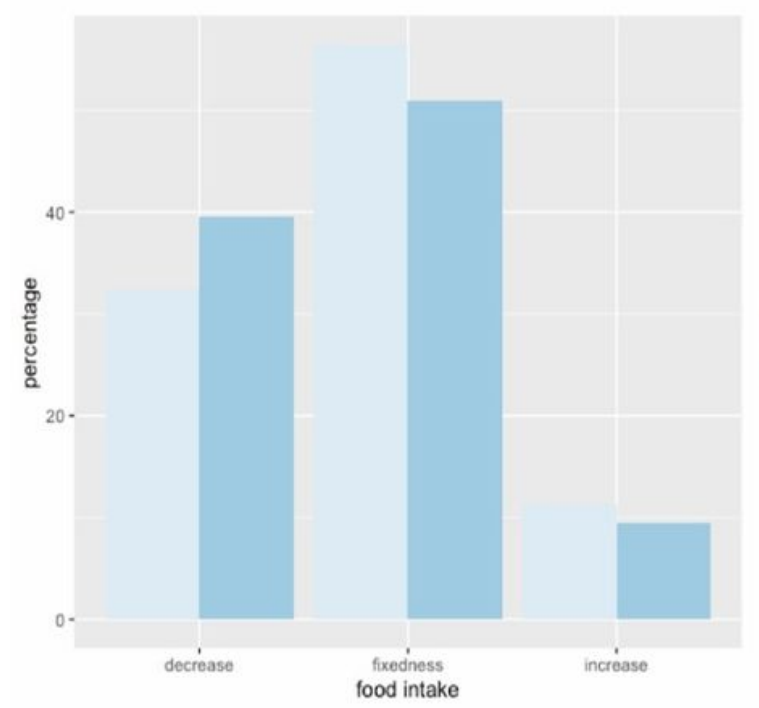

$\mathrm{B}$

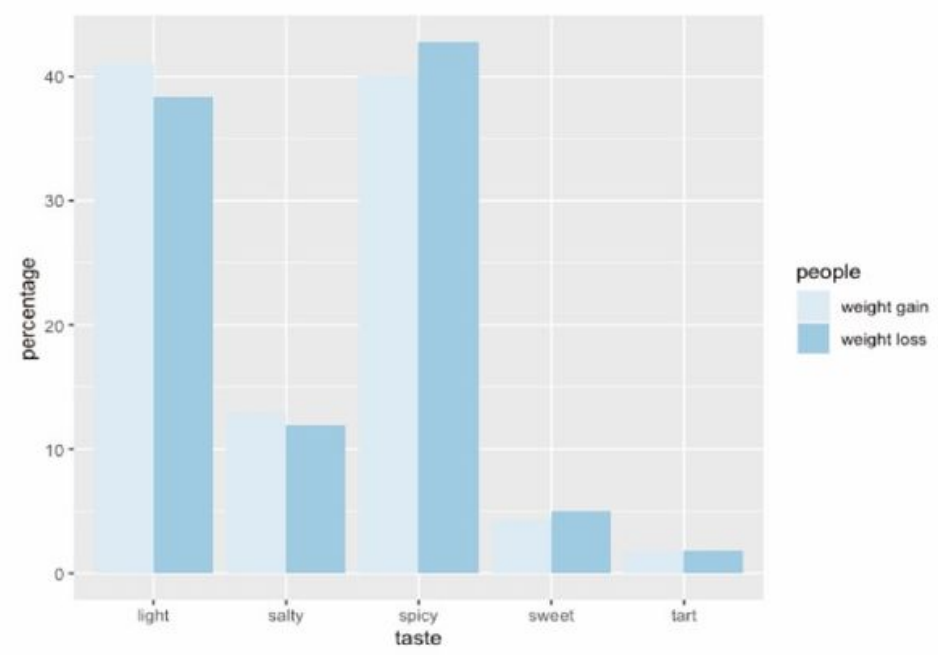

$\mathrm{D}$

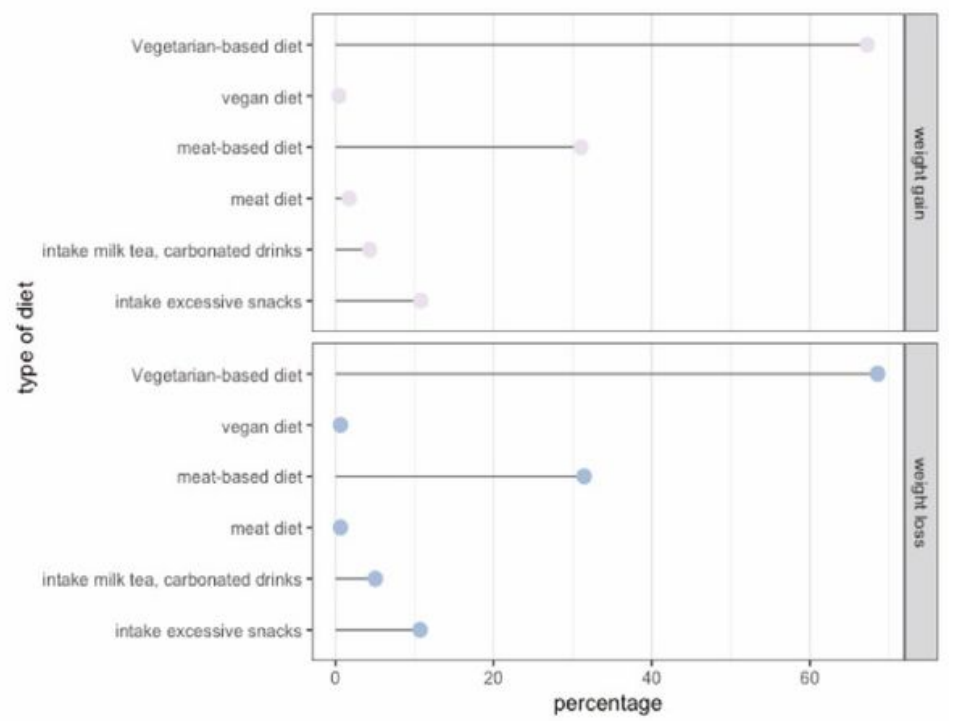

\section{Figure 3}

The differences of diet between weight gain group and weight loss group during self-quarantine. (A) eating habits, (B) tastes, (C) food intake, (D) type of diet.

\section{Supplementary Files}

This is a list of supplementary files associated with this preprint. Click to download.

- Supplementaryinformation.docx 